\title{
The Effectivity of Problem Based Learning with Scaffolding on Creative Thinking Ability of Senior High School Students in Terms of Gender
}

\author{
Herman Jufri Andi ${ }^{1}$, Chairatul Umamah ${ }^{2}$, Wayan Suana ${ }^{3}$ \\ Universitas Islam Madura, Indonesia ${ }^{1,2}$, Universitas Lampung, Indonesia ${ }^{3}$ \\ hermjufriandi@gmail.com ${ }^{1}$, chairatul.physics@gmail.com², wsuane@gmail.com³
}

Received: May $15^{\text {th }}, 2020$. Revised: October $10^{\text {th }}, 2020$. Accepted: November $3^{\text {rd }}, 2020$

\section{Keywords :}

Problem Based Learning;

Scaffolding; Creative Thinking

Ability; Gender

\begin{abstract}
This study aims to explain how the effectiveness of problem based learning with scaffolding on creative thinking abilities of senior high school students in terms of gender on the subject of Static Fluid. This type of research is quasi experimental using nonequivalent control group design. There are two classes in this study, namely the control class just with problem based learning and experimental class using problem based learning with scaffolding. The test instrument used was essay question. Conclusions are drawn based on results of data processing and analysis using $T$ test and two-way anova with SPSS 24.0. Based on the results of analysis and discussion, in this study the following conclusions were obtained: (1) Students creative thinking ability a taught using problem based learning with scaffolding were better than students' creative thinking ability taught using only problem based learning; (2) There are not differences in students' creative thinking abilities in terms of gender; (3) There is no an interaction between problem based learning with scaffolding with gender on students' creative thinking abilities. (4) Using problem based learning with scaffolding of students' creative thinking abilities in physics is more effective with an effect size value of 0.645 with a medium category.
\end{abstract}

\section{INTRODUCTION}

The nature of learning is an interaction between teacher and student with the intensity of communication and directed in order to purpose the objectives to be achieved. Learning objectives are good learning process. The purpose of learning physics is to deliver students in mastering concepts obtained from books, learning media or the natural surroundings [1]. A good learning process requires a process of interaction by all components involved, both between teacher and student and students with students. Physics learning process needs to be taught for more specific purpose of equipping students about procedural knowledge in the form of obtaining information, ways of science and technology, habits of scientific work and creative thinking [2]. 
Based on data from the global creativity index [3] in terms of technology, talent, and tolerance, Indonesia is ranked 115 out totally of 139 countries. This data shows that creative thinking skills in Indonesia are still low, even though the Indonesian government has integrated creative thinking ability into the education system. This is formulated in Law no. 20 of 2003 concerning the national education system which aims to develop students potential to become human beings who believe and fear God Almighty, have noble character, are healthy, knowledgeable, capable, creative, independent, and become democratic and responsible citizens.

Learning activities by considering of creative thinking ability can give birth to something new in the form of ideas and real work by using learning models that are compatible with physics learning [4]. The ability of creative thinking that has not been optimized in learning model only makes students can remember and repeat learning material without developing their creative thinking abilities [5]. Dimensions of creative thinking skills include: fluency thinking skills (Fluency), flexible thinking skills (Flexibility), original thinking skills (Originality), elaboration skills (Elaboration) [6].

One of learning models that gives students the opportunity to develop creative thinking ability is problem based learning [7]. Problem based learning is built with the idea of constructivism and learning approaches with the aim that students focus on solving problems in real contexts, which will encourage them to think of situations when tried to solve problems [7]. This learning model is done through student collaboration in small groups, using a student-centered learning approach, the teacher acts as a facilitator and uses real life situations as the focus of learning. Students will work in groups to solve real and complex problems that will develop problem solving skills, reasoning, communication, and selfevaluation skills.

The advantages of using PBL [8], with PBL there will be meaningful learning. Students who learn to solve a problem will apply the knowledge they have or try to find out the necessary of knowledge. Learning can be more meaningful and expanded when students are faced with situations in which the concept is applied. One of the strategies used is scaffolding. Scaffolding is the provision of assistance to children during the early stages of their development and reduces that assistance and provides opportunities for children to take over greater responsibility as soon as the child can do it [9]. So that the provision of scaffolding will later train children to be independent after getting sufficient assistance [10].

In addition to the learning strategy factor, gender factors also influence of students' creative thinking ability. Based on the results of previous research, it shows that gender differences have a role in explaining a person's profile in solving problems and thinking creatively, although these differences are not consistent. According to Blundy \& Wood [11], it's explain that gender development could also be seen from brain development. Furthermore, Blundy \& Wood explained that in men their left brain is more developed so that they are able to think logically, think abstractly, and think analytically, while in women their right brain is more developed, so that they tend to be active in artistic, holistic, imaginative, intuitive thinking, and several abilities. visual [12]. High intelligence in women tends to never have a thorough interest in theoretical problems like men. Women are closer to practical and concrete problems of life, while men are more interested in abstract aspects.

Based on the preliminary description, the purpose of this study is to determine: 1) How is the effectiveness of using PBL with scaffolding on students' creative thinking ability in terms of gender; 2) How does gender influence students' creative thinking ability using PBL with scaffolding.

\section{METHOD}

The research method used in this study is quasi experimental design. The design used in this study is nonequivalent control group design. The population in this study was SMA Negeri 4 Pamekasan class $\mathrm{X}-\mathrm{A}$ as an experimental class using the problem based learning model with scaffolding and class X-B 
The Effectivity of Problem Based Learning with Scaffolding on Creative Thinking Ability... Herman Jufri Andi, Chairatul Umamah, Wayan Suana

as a control class using just problem based learning model. While the samples in this study are:

Table 1. Distribution Number of Research Objects

\begin{tabular}{cccc}
\hline Class & Male & Female & Total \\
\hline Experiment & 9 & 13 & 22 \\
Control & 12 & 10 & 22 \\
\hline
\end{tabular}

The variables in this study are:

Independent variable $(\mathrm{X})$ : Problem based learning with scaffolding.

Dependent variable $\left(\mathrm{Y}_{1}\right)$ : Students' creative thinking ability.

Dependent variable $\left(\mathrm{Y}_{2}\right)$ : Amount of gender.

This study design is shown in Table 2 .

Table 2. Research Design

\begin{tabular}{ccc}
\hline Pretest & Treatment & Posttest \\
\hline $\mathrm{O}_{1}$ & $\mathrm{X}_{1}$ & $\mathrm{O}_{2}$ \\
$\mathrm{O}_{3}$ & $\mathrm{X}_{2}$ & $\mathrm{O}_{4}$ \\
\hline
\end{tabular}

Information:

$\mathrm{O}_{1}$ and $\mathrm{O}_{3}=$ Measurement of the initial ability of the experimental and control groups.

$\mathrm{O}_{2}$ and $\mathrm{O}_{4}=$ Measurement of the final ability of the experimental and control groups.

$\mathrm{X}_{1} \quad=$ Treatment given to the experimental class, namely learning activities with problem based learning with scaffolding.

$\mathrm{X}_{2}=$ Treatment given to the control class, namely learning activities just with problem based learning.

The creative thinking ability data was obtained through a distributed ability test on 10 reliable problem descriptions given before and after treatment. The questions that are used (aspects of research) include: fluency thinking skills, flexibility thinking skills, original thinking skills, elaboration skills.

Table 3. Creative Thinking Assessment Rubric

\begin{tabular}{|c|c|c|c|}
\hline Aspect & $\begin{array}{c}\text { Assessment } \\
\text { Indicators }\end{array}$ & Student Responses to Questions & Score \\
\hline \multirow{5}{*}{ Fluency } & \multirow{5}{*}{$\begin{array}{l}\text { Fluency to provides } \\
\text { an idea in the } \\
\text { concept of collision. }\end{array}$} & $\begin{array}{l}\text { Provide more than one idea that is relevant to problem } \\
\text { solving and its disclosure is complete and clear. }\end{array}$ & 4 \\
\hline & & $\begin{array}{l}\text { Provide more than one idea that is relevant to problem } \\
\text { solving but the expression is less clear. }\end{array}$ & 3 \\
\hline & & $\begin{array}{l}\text { Provide one idea that is relevant to problem solving and its } \\
\text { disclosure is complete and clear. }\end{array}$ & 2 \\
\hline & & $\begin{array}{l}\text { Provide one idea that is relevant to problem solving but it is } \\
\text { less clear in its expression. }\end{array}$ & 1 \\
\hline & & Not answering / giving irrelevant ideas for problem solving. & 0 \\
\hline \multirow{5}{*}{ Flexibility } & \multirow{5}{*}{$\begin{array}{l}\text { Flexibility to provide } \\
\text { of various } \\
\text { interpretations for an } \\
\text { image, story or } \\
\text { problem in the } \\
\text { concept of } \\
\text { momentum. }\end{array}$} & $\begin{array}{l}\text { Provide answers in more than one way (various), the } \\
\text { thought process and the results are correct. }\end{array}$ & 4 \\
\hline & & $\begin{array}{l}\text { Give answers in more than one way (various), but the } \\
\text { results are wrong because there are mistakes in the } \\
\text { approach / thought process. }\end{array}$ & 3 \\
\hline & & $\begin{array}{l}\text { Give answers in one way, the thought process and the } \\
\text { results are correct. }\end{array}$ & 2 \\
\hline & & $\begin{array}{l}\text { Providing answers only in one way and there is an error in } \\
\text { the approach / thought process. }\end{array}$ & 1 \\
\hline & & Not answering / giving irrelevant ideas for problem solving. & 0 \\
\hline
\end{tabular}




\begin{tabular}{|c|c|c|c|}
\hline Aspect & $\begin{array}{c}\text { Assessment } \\
\text { Indicators }\end{array}$ & Student Responses to Questions & Score \\
\hline \multirow{5}{*}{ Originality } & \multirow{5}{*}{$\begin{array}{l}\text { Originality in } \\
\text { choosing of other } \\
\text { thinking way than } \\
\text { others in the } \\
\text { concepts of } \\
\text { momentum and } \\
\text { impulse. }\end{array}$} & $\begin{array}{l}\text { Provide answers in their own way and the disclosure } \\
\text { process and the answers are correct. }\end{array}$ & 4 \\
\hline & & $\begin{array}{l}\text { Giving answers is not in their own way and the disclosure } \\
\text { process and the answers are correct. }\end{array}$ & 3 \\
\hline & & $\begin{array}{l}\text { Providing answers in their own way, the disclosure process } \\
\text { is focused but not complete. }\end{array}$ & 2 \\
\hline & & Gives its own answer but cannot be understood. & 1 \\
\hline & & Not answering / giving wrong answers. & 0 \\
\hline \multirow{5}{*}{ Elaboration } & \multirow{5}{*}{$\begin{array}{l}\text { Elaboration in deeper } \\
\text { problem solving with } \\
\text { several detailed steps } \\
\text { on the concept of } \\
\text { momentum and } \\
\text { impulse relationship. }\end{array}$} & Extend the situation properly and detail it in completely & 4 \\
\hline & & Extends the situation properly but goes into less detail. & 3 \\
\hline & & $\begin{array}{l}\text { There was a mistake in expanding the situation and was } \\
\text { accompanied by less detailed details. }\end{array}$ & 2 \\
\hline & & $\begin{array}{l}\text { There is a mistake in extending the situation without } \\
\text { elaborating. }\end{array}$ & 1 \\
\hline & & Not answering / giving wrong answers. & 0 \\
\hline
\end{tabular}

After obtaining data on the ability to think creatively, the prerequisite test analysis is normality and homogeneity. After finding that the data is normally distributed and has a homogeneous variance, then the data are analyzed with the two way anova test with SPSS 24.0 to find out which class has a better problem solving ability value. Effect size tests to find out how effective the learning model is used in improving problem solving skills.

Table 4. The Value of Interpretation Criteria for Cohen's d Effect Size

\begin{tabular}{ccc}
\hline Cohen's Standard & Effect Size & Percentage (\%) \\
\hline \multirow{6}{*}{ High } & 2.0 & 97.7 \\
& 1.9 & 97.1 \\
& 1.8 & 96.4 \\
& 1.7 & 95.5 \\
& 1.6 & 94.5 \\
& 1.5 & 93.3 \\
& 1.4 & 91.9 \\
& 1.3 & 90 \\
& 1.2 & 88 \\
& 1.1 & 86 \\
Medium & 1.0 & 84 \\
& 0.9 & 82 \\
Low & 0.8 & 79 \\
& 0.7 & 76 \\
& 0.6 & 73 \\
& 0.5 & 69 \\
\hline \multirow{3}{*}{ Low } & 66 \\
& 0.4 & 62 \\
\end{tabular}

\section{RESULTS AND DISCUSSIONS}

Creative thinking ability Data can be seen in Table 5. From Table 5 it can be seen that from the amount 22 students, the mean value of creative thinking ability results with Problem Based Learning with Scaffolding is 35.5 while the standard deviation is 1.225 for a maximum score of 40 . The average value of 22 student's for creative thinking ability with only problem based learning model was 34.55 , while 
The Effectivity of Problem Based Learning with Scaffolding on Creative Thinking Ability... Herman Jufri Andi, Chairatul Umamah, Wayan Suana

the standard deviation was 1.532 for a maximum score of 40 .

Table 5. Summary of Data Creative Thinking Ability

\begin{tabular}{rlccc}
\hline Gender & Learning Model & Mean & Std. Deviation & $\mathbf{N}$ \\
\hline \multirow{3}{*}{ Male } & Problem Based Learning with Scaffolding & 36.00 & 1.323 & 9 \\
\cline { 2 - 5 } & Problem Based Learning & 34.67 & 1.923 & 12 \\
\cline { 2 - 5 } & Total & 35.24 & 1.786 & 21 \\
\hline \multirow{3}{*}{ Female } & Problem Based Learning with Scaffolding & 35.15 & 1.068 & 13 \\
\cline { 2 - 5 } & Problem Based Learning & 34.40 & 1.430 & 10 \\
\cline { 2 - 5 } & Total & 34.83 & 1.267 & 23 \\
\hline \multirow{3}{*}{ Total } & Problem Based Learning with Scaffolding & 35.50 & 1.225 & 22 \\
\cline { 2 - 5 } & Problem Based Learning & 34.55 & 1.683 & 22 \\
\cline { 2 - 5 } & Total & 35.02 & 1.532 & 44 \\
\hline
\end{tabular}

If further attention is paid to the average score of students' creative thinking abilities on each indicator, it shows that the mean score of students' creative thinking abilities taught using the Problem Based Learning with Scaffolding model is greater than the average score of students' creative thinking abilities taught using only Problem Based Learning model. The full score can be seen in Figure 1.

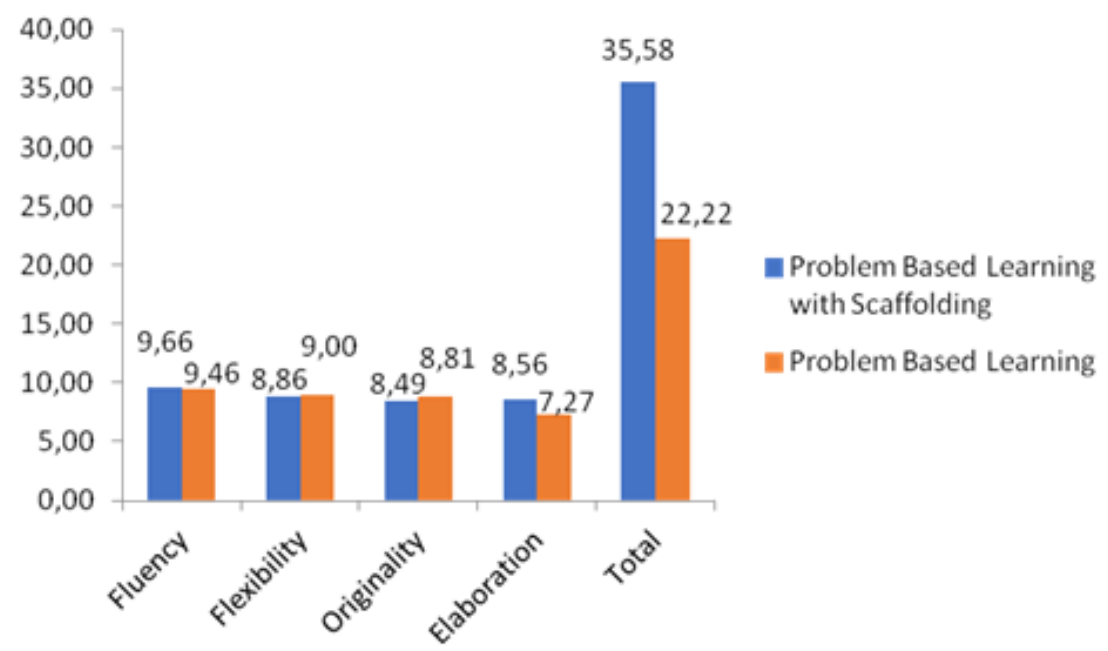

Fig 1. Histogram of Ability to Think Creative Based on Learning Models

The hypothesis of this study was analysed with two-way ANOVA, but previously the requirements (1) normality (table 6) had also been tested and (2) homogeneity (table 7).

Table 6. Normality Test (Shapiro-Wilk)

\begin{tabular}{lccc}
\hline & Statistic & df & Sig. \\
\hline Standardized Residual for Creative Thinking Ability & .966 & 44 & .208 \\
\hline
\end{tabular}

Table 7. Homogeneity Test (Levene's Test)

\begin{tabular}{cccc}
\hline $\mathbf{F}$ & df1 & df2 & Sig. \\
\hline 2.627 & 3 & 40 & .063 \\
\hline Tests the null hypothesis that the error variance of the dependent variable is
\end{tabular}

Tests the null hypothesis that the error variance of the dependent variable is equal across groups.

a. Design: Intercept + Gender + Learning_Model + Gender * Learning_Model

This anava analysis is done using SPSS 24.0 with a significance level of 5\%. Furthermore, for hypothesis test can be seen in table 8, a summary of the two-way ANOVA test. 
Table 8. Summary of the Two-Way Anava Test

\begin{tabular}{cccccc}
\hline Source & $\begin{array}{c}\text { Type III Sum } \\
\text { of Squares }\end{array}$ & df & Mean Square & F & Sig. \\
\hline Corrected Model & $14.218 \mathrm{a}$ & 3 & 4.739 & 2.185 & .105 \\
Intercept & 52944.297 & 1 & 52944.297 & 24409.831 & .000 \\
Learning_Model & 11.730 & 1 & 11.730 & 5.408 & .025 \\
Gender & 3.335 & 1 & 3.335 & 1.537 & .222 \\
Learning_Model * Gender & .904 & 1 & .904 & .417 & .522 \\
Error & 86.759 & 40 & 2.169 & & \\
Total & 54071.000 & 44 & & & \\
Corrected Total & 100.977 & 43 & & & \\
\hline
\end{tabular}

a. R Squared $=.141$ (Adjusted R Squared $=.076)$

The results of first hypothesis analysis show that: Learning proses with Problem Based Learning with Scaffolding and only Problem Based Learning has a different effect on creative thinking ability. The results of the first study showed that students who were taught using Problem Based Learning with Scaffolding had different creative thinking abilities from students which is taught using only Problem Based Learning $\left(\mathrm{F}_{\text {count }}=5.408\right.$ with a significance of 0.025 which was smaller than 0.05$)$. Meanwhile, when viewed from the average creative thinking ability of students which is taught using Problem Based Learning with Scaffolding is 35.5 and it is better than the average creative thinking ability of students taught using only Problem Based Learning while the value is 34.55 .

These results are consistent [13], by changing the focus of certain materials to achieve broader educational goals, Problem based learning can help individuals become experts in material, and good problem solvers. When students are faced with problems, their creative thinking ability will be sharpened by showing creative attitudes (1) The desire / need to change / develop (improve); (2) Seeing a situation / problem from the other side (see differenty) which implies "think outside of the box"; (3) Open to various ideas, even the unusual ones (open); (4) Implementing improvement ideas (acting).

The issue of improving students' creative thinking ability was conveyed by many experts among them, that $2 / 3$ of creative thinking abilities is obtained through education, the remaining $1 / 3$ comes from genetics [14]. On the other hand, for the ability of intelligence, it is true that $1 / 3$ of the ability of intelligence obtained from education, the remaining $2 / 3$ from genetics. It means that we can't do much anything to increase someone's intelligence but we have many opportunities to increase one's creativity. Furthermore, Widodo found that intelligence-based learning produced no results significant (only $50 \%$ increase) compared to creativity based (up to 200\%) [14].

If viewed according to gender (in Table 5), it can be seen that the number of students who have a male gender is 21 . The mean value of students who have male gender is 35.24 and the standard deviation of students who have male gender is 1.786 . Meanwhile, the number of students who have female gender is 23 . The mean value of students who have female gender is 34.83 and the standard deviation of students who have female gender is 1.267 .

If further attention is paid to the average score of students' creative thinking abilities on each indicator, based on gender, it shows that the mean score of male students' creative thinking abilities is greater than the average score of female students' creative thinking abilities. The complete score can be seen in Table 9.

Table 9. Summary of Data on Creative Thinking Ability by Gender

\begin{tabular}{cccccc}
\hline & Fluency & Flexibility & Originality & Elaboration & Total \\
\hline Male & 9.60 & 9.06 & 8.68 & 8.00 & 29.38 \\
Female & 9.52 & 8.81 & 8.62 & 7.83 & 28.42 \\
\hline
\end{tabular}


The results of second hypothesis analysis found that: Male students 'creative thinking abilities did not have a significant difference with female students' creative thinking abilities. It is indicated by $\left(\mathrm{F}_{\text {count }}=\right.$ 1.537 with a significant 0.222 which is greater than 0.05 ) as shown in Table 8 . Furthemore at Table 5 that the average of student creative thinking ability who have male gender is 29.38 better than the average student creative thinking ability who have female gender 28.42. These results indicate that the superiority of male students in creative thinking abilities compared to female students' ability to think creatively. These results are consistent [15] that boys are more creative than girls.

The results of third hypothesis analysis show that: there is an interaction between Problem Based Learning with Scaffolding and only Problem Based Learning models with gender on creative thninking ability. The results of this study are indicated by $\left(\mathrm{F}_{\text {count }}=0.417\right.$ with a significant 0.522 which is greater than 0.05). The existence of this interaction shows that the inconsistency of findings on differences in creative thinking abilities with gender. This result was also expressed by Kesianye which stated that there was no clear difference regarding the creative thinking abilities of boys and girls [16]. It also shows that certain learning models cannot be applied to all students.

In other words, that the absence of differences in creative thinking abilities caused by learning model cannot be separated from the influence of gender differences. And conversely, the differences in creative thinking abilities caused by the gender of students cannot be separated from the differences in learning models. This also shows that the effect of learning model cannot be separated from the existence of gender variables. Although it has been shown that Problem Based Learning with Scaffolding and only Problem Based Learning provide different creative thinking ability, male students make a greater contribution than female students.

According to Kesianye [16] also disclosed some of the findings experts regarding differences in learning achievement based on gender are as follows: (1) there were no clear differences regarding the math abilities of male and female. (2) the difference in type gender has no effect on solving ability problem. (3) girls tend to underestimate their potential while boys are too much of their potential. (4) boys' test scores were more spread out than children women who tend to be around mean. In terms of memorizing women superior to men while in divergent thinking the opposite. (5) men are superior in spatial (spatial) skills while women are superior in terms of verbal skills.

If we look closely, the average creative thinking ability of male and female students using Problem Based Learning with Scaffolding are 36.00 and 35.15; respectively, as shown in Table 10. It shows that male students' creative thinking abilities are better than female students' creative thinking abilities. This shows that Problem Based Learning with Scaffolding can improve students' creative thinking skills regardless of gender.

Table 10. Summary of Data on Creative Thinking Ability using Problem Based Learning with Scaffolding Based on Gender

\begin{tabular}{cccccc}
\hline & Fluency & Flexibility & Originality & Elaboration & Total \\
\hline Male & 9.78 & 9.11 & 8.44 & 8.67 & 36.00 \\
Female & 9.54 & 8.62 & 8.54 & 8.46 & 35.15 \\
\hline
\end{tabular}

In table 11, its show that mean creative thinking ability of male and female students using Problem Based Learning are 22.77 and 21.68, respectively.

Table 11. Summary of Data on Creative Thinking Ability using Problem Based Learning Based on Gender

\begin{tabular}{cccccc}
\hline & Fluency & Flexibility & Originality & Elaboration & Total \\
\hline Male & 9.42 & 9.00 & 8.92 & 7.33 & 22.77 \\
Female & 9.50 & 9.00 & 8.70 & 7.20 & 21.68 \\
\hline
\end{tabular}


The creative thinking ability of male students who were taught using only Problem Based Learning learning was better than that of female students. This shows that the creative thinking abilities of female students do not develop well using only Problem Based Learning learning.

The effectiveness of the problem based learning model with Scaffolding, the effect size is calculated. Based on the calculation of effect size, it can be seen in the following table 12.

Table 12. Effect Size Test

\begin{tabular}{ccccc}
\hline & Mean & $\begin{array}{c}\text { Standard } \\
\text { Deviation }\end{array}$ & $\begin{array}{c}\text { Effect } \\
\text { Size }\end{array}$ & $\begin{array}{c}\text { Cohen's } \\
\text { Standard }\end{array}$ \\
\hline $\begin{array}{c}\text { Problem Based Learning with Scaffolding } \\
\text { Problem Based Learning }\end{array}$ & 35.5 & 1.225 & 0.645 & Medium \\
\hline
\end{tabular}

When the result seen from magnitude of the effect size number is 0.645 (relatively medium based on table 4 ) or only contributed $73 \%$ of students' creative thinking abilities in the experimental class. From the effect size test results, the problem based learning with scaffolding in senior high school students' creative thinking abilities in physics is more effective than the only problem based learning.

\section{CONCLUSION AND SUGGESTION}

Based on the results of analysis and discussion, in this study the following conclusions were obtained: (1) Students creative thinking ability a taught using problem based learning with scaffolding were better than students' creative thinking ability taught using only problem based learning; (2) There are not differences in students' creative thinking abilities in terms of gender; (3) There is no an interaction between problem based learning with scaffolding with gender on students' creative thinking abilities. (4) Using problem based learning with scaffolding of students' creative thinking abilities in physics is more effective with an effect size value of 0.645 with a medium category.

Based on the research results, it is suggested that the researcher or physics teacher be able to design a problem based learning with scaffolding. The absence of interaction between model and gender reminds the researcher not to ignore gender factors in determining learning strategies and models.

\section{ACKNOWLEDGMENTS}

We would like to thank the headmaster, teachers, students and educational staff of SMA Negeri 4 Pamekasan, so this research activities can run smoothly. We also would like to thank FKIP UIM academic community for the permission given in conducting this research.

\section{REFERENCES}

[1] Halim, A., Suriana, S., \& Mursal, M. (2017). Dampak problem based learning terhadap pemahaman konsep ditinjau dari gaya berpikir siswa pada mata pelajaran Fisika. Jurnal Penelitian \& Pengembangan Pendidikan Fisika, 3(1): 1-10.

[2] Islamiah, A. F., Rahayu, S., \& Verawati, N. N. S. P. (2018). Efektivitas Model Pembelajaran Problem Based Learning Berbantuan Lks Terhadap Kemampuan Berpikir Kritis Fisika Siswa Sman 1 Lingsar Tahun Ajaran 2016/2017. Lensa: Jurnal Kependidikan Fisika, 6(1): 29-36.

[3] Florida, R., Mellander, C., \& King, K. (2015). The global creativity index 2015. Martin Prosperity Institute.

[4] Ramadhani, R. (2017). Peningkatan Kemampuan Pemecahan Masalah Matematika Ditinjau dari Gender Melalui Pembelajaran Berbasis Masalah Berkarakter pada Siswa Kelas XI SMA YPK Medan. Jurnal Edukasi Matematika, 8(15): 924-932. 
[5] Yuliawanti, E., Suciati, S., \& Ariyanto, J. (2019). Pengaruh Model Problem Based Learning dengan Scaffolding Learning Activities terhadap Kemampuan Memecahkan Masalah Siswa. BioPedagogi, 8(1): 23-29.

[6] Utami, R. P., Probosari, R. M., \& Fatmawati, U. M. I. (2015). Pengaruh Model Pembelajaran Project Based Learning Berbantu Instagram Terhadap Kemampuan Berpikir Kreatif Siswa Kelas X SMA Negeri 8 Surakarta. Bio-Pedagogi, 4(1): 47-52.

[7] Elizabeth, A., \& Sigahitong, M. M. (2018). Pengaruh Model Problem Based Learning Terhadap Kemampuan Berpikir Kreatif Peserta Didik SMA. Prisma Sains: Jurnal Pengkajian Ilmu dan Pembelajaran Matematika dan IPA IKIP Mataram, 6(2): 66-76.

[8] Wulandari, B., \& Surjono, H. D. (2013). Pengaruh problem-based learning terhadap hasil belajar ditinjau dari motivasi belajar PLC di SMK. Jurnal Pendidikan Vokasi, 3(2).

[9] Fatimah, S. I., Astutik, S., \& Supeno, S. (2019). Pengaruh LKS Berbantuan Scaffolding Dalam Model Creative Problem Solving (CPS) Terhadap Kreativitas Ilmiah Fisika Siswa SMA. Jurnal Pembelajaran Fisika, 8(3): 187-194.

[10] Sutiarso, S. (2009, June). Scaffolding dalam pembelajaran matematika. In Prosiding Seminar Nasional Penelitian, Pendidikan dan Penerapan MIPA Fakultas MIPA, Universitas Negeri Yogyakarta, Yogyakarta (Vol. 16).

[11] Blundy, J., \& Wood, B. (1994). Prediction of crystal-melt partition coefficients from elastic moduli. Nature, 372(6505): 452-454.

[12] Hodiyanto, H. (2017). Pengaruh model pembelajaran problem solving terhadap kemampuan komunikasi matematis ditinjau dari gender. Jurnal Riset Pendidikan Matematika, 4(2): 219-228.

[13] Dunlap, J. C. (2005). Problem-based learning and self-efficacy: How a capstone course prepares students for a profession. Educational Technology Research and Development, 53(1): 65-83.

[14] Widodo, S. (2012). Profil Kreativitas Guru SMP dalam Membuat Masalah Matematika Kontekstual Berdasarkan Kualifikasi Akademik. In Seminar Nasional Matematika dan Pendidikan Matematika.

[15] Amanda, R. (2020). Peran Knowledge Sharing dalam Meningkatkan Employee Creativity Melalui Leader-Member Exchange (LMX) pada Tim Kerja Xavier Marks Realty. Jurnal Ilmu Manajemen $(J I M), 8(1)$.

[16] Kesianye, S. K. (2015). The Three Perspectives of Integrating Assessment and Instruction in the Learning of School Mathematics. Journal of Education and Practice, 6(19): 212-214. 